\title{
Phycocyanin from Arthrospira platensis as Potential Anti-Cancer Drug: Review of In Vitro and In Vivo Studies
}

\author{
Steffen Braune ${ }^{1}$, Anne Krüger-Genge ${ }^{2}$, Sarah Kammerer ${ }^{1}{ }^{\mathbb{D}}$, Friedrich Jung ${ }^{1}$ and Jan-Heiner Küpper ${ }^{1,3, *}$ \\ 1 Institute of Biotechnology, Molecular Cell Biology, Brandenburg University of Technology \\ Cottbus-Senftenberg, 01968 Senftenberg, Germany; steffen.braune@b-tu.de (S.B.); \\ sarah.kammerer@b-tu.de (S.K.); friedrich.jung@b-tu.de (F.J.) \\ 2 Department of Healthcare, Biomaterials and Cosmeceuticals, Fraunhofer-Institute for Applied Polymer Research (IAP), \\ 14476 Potsdam-Golm, Germany; anne.krueger-genge@iap.fraunhofer.de \\ 3 Carbon Biotech Social Enterprise AG, 01968 Senftenberg, Germany \\ * Correspondence: Jan-Heiner.Kuepper@b-tu.de
}

check for

updates

Citation: Braune, S.; Krüger-Genge, A.; Kammerer, S.; Jung, F.; Küpper, J.-H. Phycocyanin from Arthrospira platensis as Potential Anti-Cancer Drug: Review of In Vitro and In Vivo Studies. Life 2021, 11, 91. https:// doi.org/10.3390/life11020091

Received: 4 December 2020

Accepted: 22 January 2021

Published: 27 January 2021

Publisher's Note: MDPI stays neutral with regard to jurisdictional claims in published maps and institutional affiliations.

Copyright: (c) 2021 by the authors. Licensee MDPI, Basel, Switzerland. This article is an open access article distributed under the terms and conditions of the Creative Commons Attribution (CC BY) license (https:// creativecommons.org/licenses/by/ $4.0 /)$.

\begin{abstract}
The application of cytostatic drugs or natural substances to inhibit cancer growth and progression is an important and evolving subject of cancer research. There has been a surge of interest in marine bioresources, particularly algae, as well as cyanobacteria and their bioactive ingredients. Dried biomass products of Arthrospira and Chlorella have been categorized as "generally recognized as safe" (GRAS) by the US Food and Drug Administration (FDA). Of particular importance is an ingredient of Arthrospira: phycocyanin, a blue-red fluorescent, water-soluble and non-toxic biliprotein pigment. It is reported to be the main active ingredient of Arthrospira and was shown to have therapeutic properties, including anti-oxidant, anti-inflammatory, immune-modulatory and anticancer activities. In the present review, in vitro and in vivo data on the effects of phycocyanin on various tumor cells and on cells from healthy tissues are summarized. The existing knowledge of underlying molecular mechanisms, and strategies to improve the efficiency of potential phycocyaninbased anti-cancer therapies are discussed.
\end{abstract}

Keywords: phycocyanin; Arthrospira platensis; cancer; tumor; drug; in vitro; in vivo

\section{Introduction}

Over the last few decades, products from natural, non-synthetic origin have become increasingly important for the prevention and treatment of cancer due to the toxic side effects of many synthetic anti-cancer drugs [1-4]. Arthrospira platensis (AP), often called "Spirulina", belongs to the phylum of cyanobacteria with characteristic photosynthetic capability [5]). These filamentous, gram-negative cyanobacteria or blue-green algae are considered as one of the sources of such natural bioactive substances (Figure 1) [6,7].

Up to now, in vivo toxicology studies of AP have not revealed any toxic effects on kidney, liver, reproductive system, or body physiology during or after the administration of acute or chronic doses [8-10]. A safety evaluation by the United States Pharmacopoeiabased on a 1966 to 2009 PUBMED literature review-and adverse event reports of the United States Food and Drug Administration (FDA) concluded that AP has a Class A safety [11].

Several dried biomass products of AP have also been categorized as "generally recognized as safe" (GRAS) by the FDA. A recommended dosage for adults is usually in the range of 3-10 g of AP per day. Maximally applied AP doses of $30 \mathrm{~g} /$ day did not lead to any negative side effects [12]. The regular consumption of considerably lower AP dry mass (but also phycocyanin) was shown to reduce intestinal inflammation, to improve the permeability of the intestinal tissue, and to increase the diversity of the intestinal microbiota e.g., in high-fat-diet rats (e.g., $3 \mathrm{~g}$ of AP per day) but also in apparently healthy mice (e.g., $2.1 \mathrm{~g}$ of AP per day) [13-16]. 

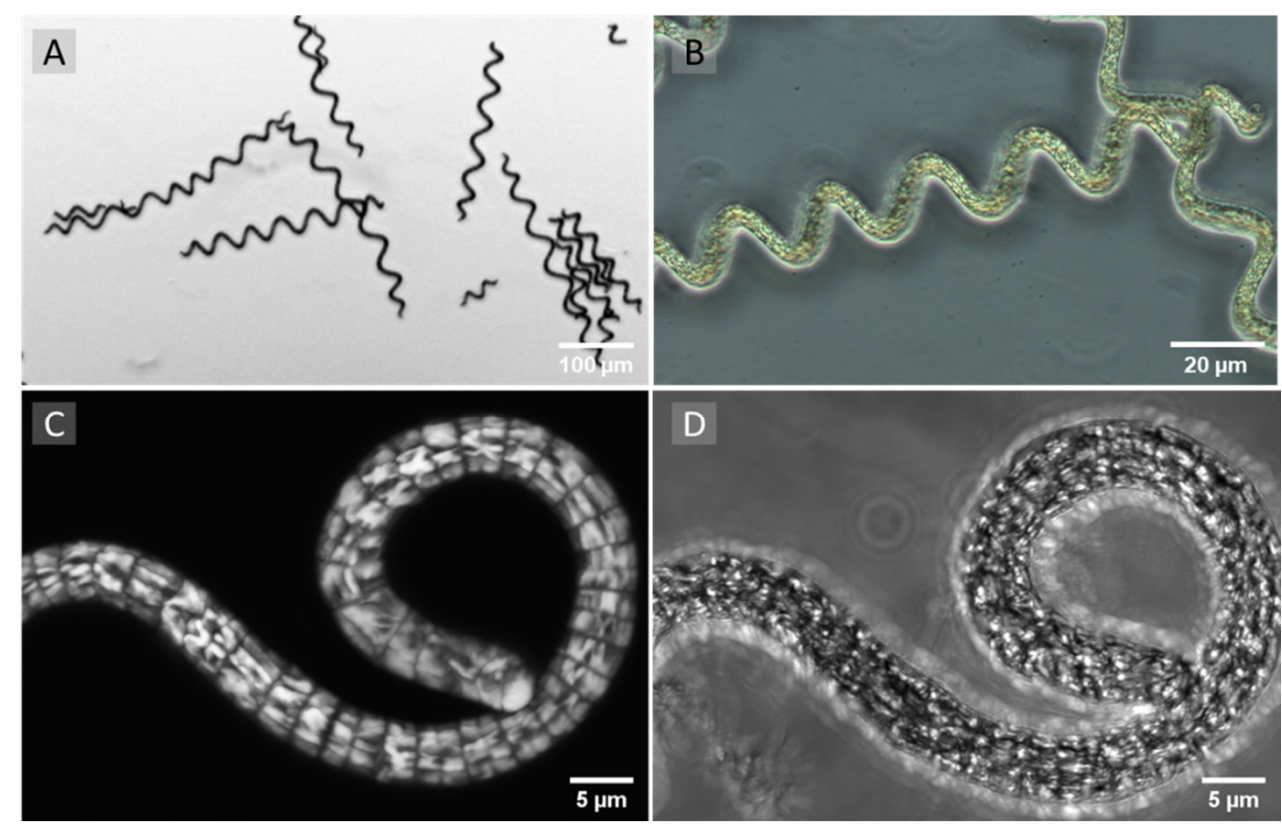

Figure 1. (A,B) Representative phase contrast images of unfixed Arthrospira platensis (AP). (C) Orthogonal projection of a three-dimensional laser scanning microscopy image stack (47 single images) of $A P$. Label-free laser scanning microscopy of an unfixed sample. The sample was exited at a $555 \mathrm{~nm}$ wavelength. Emissions were detected between $650 \mathrm{~nm}$ and $700 \mathrm{~nm}$. (D) Transmitted mode image of the same position. Images were taken at 100-fold primary magnification with an Axio Observer.Z1/7 (Carl Zeiss Microscopy, Jena, Germany).

Analyses of the amino acid composition showed that AP is nutritionally at least comparable to soy, and close to the World Health Organization/Food and Agriculture Organization of the United Nations' (WHO/FAO) standard of optimal protein intake [17]. In addition, $\mathrm{AP}$ is considered to be a source of minerals, vitamins and anti-oxidants including phycocyanin (PC), carotenoids, tocopherols and phenolic compounds [6,7,12,18-25]. Depending on the production and extraction process, two of the ingredients are described to affect tumor cells: PC and exopolysaccharides. However, since Challouf et al. were recently able to show that extracellular polysaccharides are not present in aqueous extracts and had no cytotoxic effect on tumor cells [26], PC can be considered a key active substance. Further ingredients that affect cell functions are chlorophyll, phycoerythrin, vitamin $C, \gamma$-linoleic acids, and $\alpha$-tocopherol [27-31]. The latter are only present in minute quantities in AP or are not described to affect tumor cells.

PC is an oligomeric protein consisting of equal numbers of $\alpha$ and $\beta$ subunits (with a molecular weight of about 18 and $21 \mathrm{kDa}$, respectively) [32,33]. The $\alpha \beta$-pairs mostly build the pigment as a trimer $(\alpha \beta) 3$ or hexamer $(\alpha \beta) 6$. Both $\alpha$ and $\beta$ subunits have a bilin chromophore, which contains linear tetrapyrrole rings that are attached to the cysteine amino acid of the apoprotein by thioether linkages [34]. Medical applications of PC are of interest due to its anti-inflammatory, anti-viral, anti-cancer, immunostimulatory and anti-oxidant properties [35].

Recent anti-cancer studies of PC revealed a significant inhibitory effect on the growth of cancer cells in a time- and dose-dependent manner. Multiple mechanisms have been found, including the induction of apoptosis, cell cycle arrest, inhibition of DNA replication and the generation of reactive oxygen species (ROS) [32,36-38]. While apoptosis was significantly increased in cancerous cells, PC had a considerably lower toxicity on cells from healthy tissues, which makes it an appropriate candidate for chemotherapeutic applications $[35,39,40]$.

In the present review, we summarize the effects of PC on cells that originate from various tumors, or on cells from healthy tissue in in vitro and in vivo studies. In addition, the existing knowledge of underlying molecular mechanisms are discussed. 


\section{Anti-Cancer Effects of Phycocyanin}

PC is a blue-red fluorescent ( $\sim 650 \mathrm{~nm}$ emission), water-soluble, non-toxic biliprotein pigment $[33,41]$. It is reported to be the main active ingredient of AP [42] and has been shown to have therapeutic properties, including anti-cancer activities [43-45]. At the cellular level, basic characteristics of tumor cells include unregulated cell proliferation, cellular immortalization, invasive cell growth, and in many cases, loss of capability for apoptosis [46]. The pharmacological effects of cytostatic medications in general aim to inhibit tumor cell proliferation by cell cycle arrest or induction of tumor cell death. Most cytostatic drugs are derived from natural compounds [47].

Accumulating evidence suggests that PC has a potent anti-cancer effect on various cancer types (such as breast cancer [48,49], liver cancer [50], lung cancer [51,52], colon cancer [53], leukemia [42] and bone marrow cancer [54]) in vitro and in vivo. On the other hand, even high-dose PC treatment does not induce significant toxic symptoms or mortality in animal experiments $[55,56]$.

Table 1 summarizes results of in vitro studies concerning analyzed tumor types, used cell lines, the PC concentrations for the cell growth experiments and application times, cell proliferation, half maximal inhibitory concentrations (IC50) and cell morphology. Although concentrations and exposure times-and possibly also PC purity—differed greatly between the studies, the results clearly showed cell cycle arrest, and often, apoptosis/necrosis of the various tumor cells was induced [55]. In contrast, PC had almost no or even slight proliferative effects on cells originating from normal tissue [35].

Table 1. Effects of phycocyanin on the growth of various tumor cell lines. (-: not given).

\begin{tabular}{|c|c|c|c|c|c|c|c|c|c|}
\hline \multirow{2}{*}{$\begin{array}{c}\text { Tumor Type } \\
\text { Cervical carcinoma }\end{array}$} & \multirow{2}{*}{$\begin{array}{c}\text { Cell Line } \\
\text { HeLa }\end{array}$} & \multicolumn{2}{|c|}{$\begin{array}{l}\text { Phycocyanin } \\
\text { Concentration }\end{array}$} & \multirow{2}{*}{$\begin{array}{c}\begin{array}{c}\text { Application Time } \\
\text { (h) }\end{array} \\
72 ; 24\end{array}$} & \multirow{2}{*}{$\begin{array}{c}\begin{array}{c}\text { Proliferation } \\
\text { (\%) }\end{array} \\
-32 ;-20\end{array}$} & \multicolumn{2}{|c|}{ IC50 } & \multirow{2}{*}{$\begin{array}{l}\text { Morphology } \\
\text { epithelial }\end{array}$} & \multirow{2}{*}{$\begin{array}{c}\text { Ref. } \\
{[57,58]}\end{array}$} \\
\hline & & $80 ; 200$ & $\mu \mathrm{g} / \mathrm{mL}$ & & & $-; 1104$ & $\mu \mathrm{g} / \mathrm{mL}$ & & \\
\hline $\begin{array}{l}\text { Human colorectal } \\
\text { adenocarcinoma }\end{array}$ & HCT116 & 50 & $\mu \mathrm{g} / \mathrm{mL}$ & 48 & -73 & 18.8 & $\mu \mathrm{g} / \mathrm{mL}$ & epithelial & [59] \\
\hline Pancreatic adenocarcinoma & Capan-1 & 100 & $\mu \mathrm{M}$ & 72 & -80 & 6.2 & $\mu \mathrm{M}$ & epithelial & [55] \\
\hline Pancreatic adenocarcinoma & BxPC3 & 100 & $\mu \mathrm{M}$ & 72 & -100 & 15.1 & $\mu \mathrm{M}$ & epithelial & 555601 \\
\hline Pancreatic adenocarcinoma & PA-TU-8902 & 0.3 & $\mathrm{~g} / \mathrm{L}$ & 24 & -82 & - & - & epithelial & {$[5 b, 60]$} \\
\hline $\begin{array}{l}\text { Human ductal pancreas } \\
\text { carcinoma }\end{array}$ & PANC-1 & 100 & $\mu \mathrm{M}$ & 72 & -70 & 12.2 & $\mu \mathrm{M}$ & epithelial & [55] \\
\hline Hepatoblastoma & HepG2 & 100 & $\mu \mathrm{M}$ & 72 & -76 & 13 & $\mu \mathrm{M}$ & epithelial & [55] \\
\hline Hepatoblastoma & HepG2 & $7 ; 50$ & $\mu \mathrm{g} / \mathrm{mL}$ & $24 ; 48$ & $-61 ;-75$ & $\begin{array}{l}1.75 \\
22.3\end{array}$ & $\mu \mathrm{g} / \mathrm{mL}$ & epithelial & {$[59,61]$} \\
\hline Prostate carcinoma & DU145 & 100 & $\mu \mathrm{M}$ & 72 & -70 & 18 & $\mu \mathrm{M}$ & epithelial & [55] \\
\hline Large cell lung cancer & $\mathrm{H} 460$ & 100 & $\mu \mathrm{M}$ & 72 & -95 & 14 & $\mu \mathrm{M}$ & epithelial & {$[55,62]$} \\
\hline Lung adenocarcinoma & A549 & 50 & $\mu \mathrm{g} / \mathrm{mL}$ & 24 & -38 & 99.2 & $\mu \mathrm{g} / \mathrm{mL}$ & epithelial & {$[55,62]$} \\
\hline Alveolar adenocarcinoma & A549 & 60 & $\mu \mathrm{g} / \mathrm{mL}$ & 48 & -64 & - & - & epithelial & [63] \\
\hline Nsc broncho carcinoma & H1299 & 4.8 & $\mu \mathrm{M}$ & 24 & -11.3 & - & - & epithelial & [33] \\
\hline Nsc broncho carcinoma & H460 & 4.8 & $\mu \mathrm{M}$ & 24 & -3.7 & - & - & epithelial & [33] \\
\hline Nsc broncho carcinoma & LTEP-A2 & 4.8 & $\mu \mathrm{M}$ & 4 & -14.5 & - & - & epithelial & [33] \\
\hline $\begin{array}{c}\text { Human colorectal } \\
\text { adenocarcinoma }\end{array}$ & HT-29 & $50 ; 200$ & $\mu \mathrm{g} / \mathrm{mL}$ & $48 ; 72$ & $-63 ;-100$ & - & - & epithelial & {$[63,64]$} \\
\hline Triple negative breast cancer & MDA-MB-231 & 20 & $\mu \mathrm{M}$ & 6 & -82 & 5.98 & $\mu \mathrm{M}$ & epithelial & [65] \\
\hline Triple negative breast cancer & MDA-MB-231 & 294 & $\mu \mathrm{g} / \mathrm{mL}$ & 24 & -30 & 294 & $\mu \mathrm{g} / \mathrm{mL}$ & epithelial & [57] \\
\hline Ductal carcinoma & BT-474 & 20 & $\mu \mathrm{M}$ & 6 & -80 & 8.45 & $\mu \mathrm{M}$ & epithelial & {$[65]$} \\
\hline Breast cancer & MCF-7 & $20 ; 100$ & $\mu \mathrm{M}$ & $6 ; 72$ & $-58 ;-65$ & $15.4 ; 33$ & $\mu \mathrm{M}$ & epithelial & {$[4,65]$} \\
\hline Breast cancer & MCF-7 & 5.66 & $\mu \mathrm{g} / \mathrm{mL}$ & 48 & - & 5.66 & $\mu \mathrm{g} / \mathrm{mL}$ & epithelial & [66] \\
\hline Breast cancer & MCF-7 & 40 & $\mu \mathrm{M}$ & 72 & -53 & - & - & epithelial & [49] \\
\hline Mammary gland adenocarcinoma & SKBR 3 & 20 & $\mu \mathrm{M}$ & 6 & -60 & 17.7 & $\mu \mathrm{M}$ & epithelial & {$[65]$} \\
\hline Squamous cell carcinoma, cervix & $\mathrm{SiHa}$ & 376 & $\mu \mathrm{g} / \mathrm{mL}$ & 24 & -35 & 376 & $\mu \mathrm{g} / \mathrm{mL}$ & epithelial & [57] \\
\hline Malignant melanoma & A375 & 40 & $\mu \mathrm{M}$ & 72 & -54 & - & - & epithelial & [49] \\
\hline Chronic myelogenous leukemia & K562 & 100 & $\mu \mathrm{M}$ & 96 & -49 & - & - & lymphoblast & {$[4267]$} \\
\hline Histiocytic tumor & AK-5 & 60 & $\mu \mathrm{M}$ & 72 & -70 & 60 & $\mu \mathrm{M}$ & macrophage & {$[42,6 /]$} \\
\hline
\end{tabular}

\section{Molecular Mechanisms of Phycocyanin-Induced Cell Death in Tumor Cells}

An important mechanism to treat tumors is the induction of cell apoptosis. Various pathways have been described by which PC can impair tumor cells and induce apoptosis [57]. Mechanistically, PC exerts its anti-cancer activity by reducing cell proliferation and migration and inducing apoptosis, as well as cell cycle arrest (Figure 2). Obviously, PC can penetrate the cell membrane of in vitro cultivated tumor cells since it was found in the cytosol of HepG2 cells after treatment [68]. Localized near mitochondria, it was 
shown to induce apoptosis and necrosis via mitochondria-dependent intrinsic pathways. Li et al. demonstrated that PC inhibited the growth of HeLa cells in a dose-dependent manner [58]. It activated the mitochondrial cytochrome c pathway by altering the Bcl-2/Bax ratio (Bcl-2, anti-apoptotic protein; Bax, pro-apoptotic protein; Bcl-2/Bax ratio represents the degree of apoptosis induction). Further, activation of caspases and induction of poly (ADP-ribose) polymerase-1 (PARP-1) cleavage was shown by Subhashini and coworkers [42]. PARP-1 cleavage and inactivation might disable the immediate cellular response to DNA damages such as DNA excision repair [69]. After the supplementation of PC to the supernatant of tumor cells, remarkable morphological changes were observed. These comprised cell shrinkage, formation of membrane blebs, nuclear and cytoplasmic condensation, endolytic cleavage of the DNA into small oligo-nucleosomal fragments, formation of apoptotic bodies, and micronuclei characteristic of apoptosis (Figure 3). These results are well in line with earlier studies in which cancer cells treated with anti-cancer agents showed typical morphological signs of apoptosis, such as shrinkage and membrane bleb formation $[58,64,70]$.

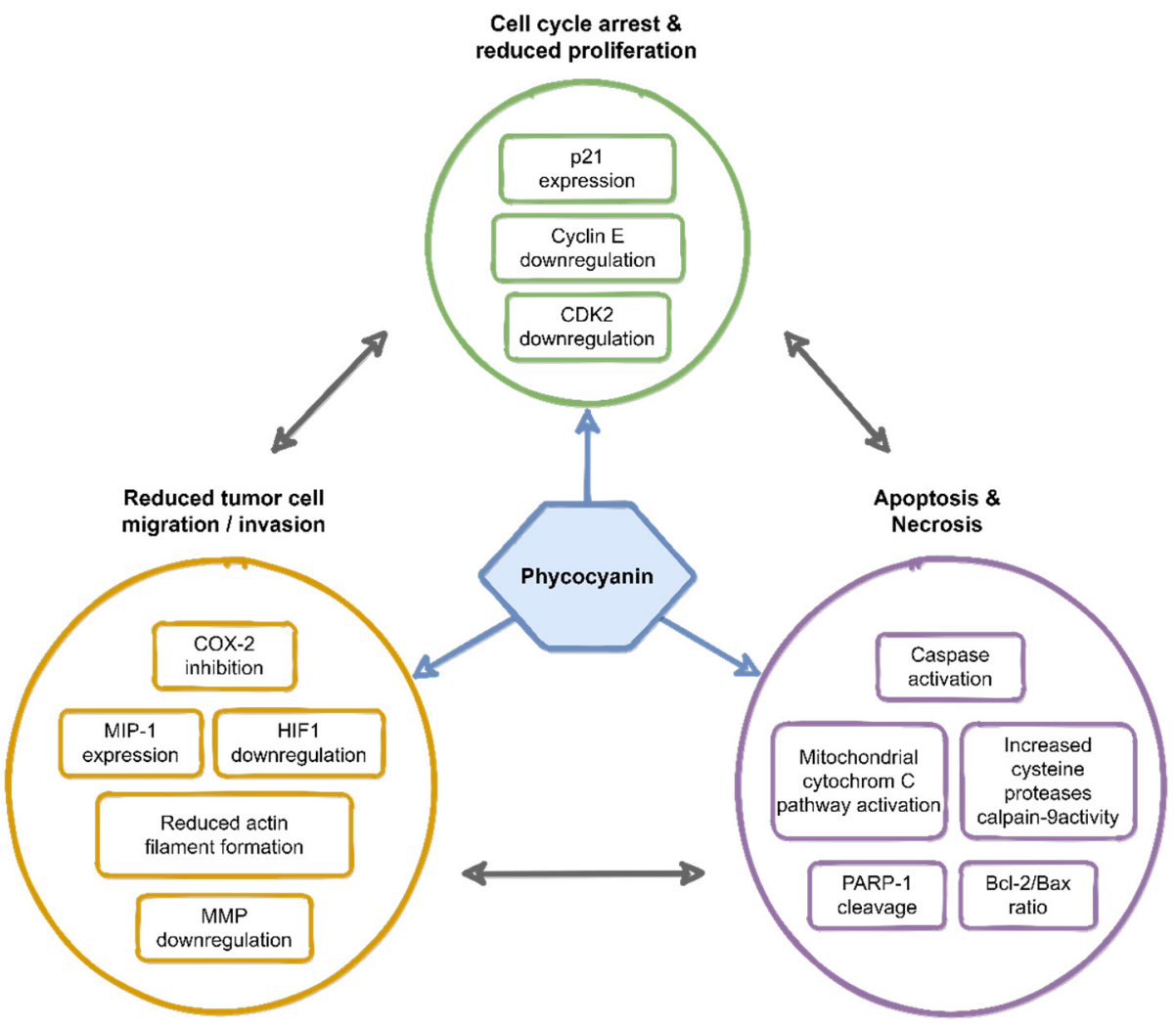

Figure 2. Overview of the reported molecular mechanisms of phycocyanin-induced anti-cancer activity.

PC also affected tumor cell invasion. In MDA-MB-231 breast cancer cells, actin filaments were reduced while the migration potential decreased with PC supplementation [65]. PC is an inhibitor of cyclooxygenase 2 (COX-2), which converts arachidonic acid to prostaglandins and plays a key role in tumor progression and chemical resistance [71-73]. Prostaglandin-E2 is a tightly regulated product of COX-2, which promotes angiogenesis [74,75]. COX-2 inhibitors also up-regulated E-cadherin expression in Caco2 colon cancer cells [76]. Moreover, COX-2 was positively correlated with tumor invasion, metastasis, and poor prognosis in non-small cell lung cancer. 


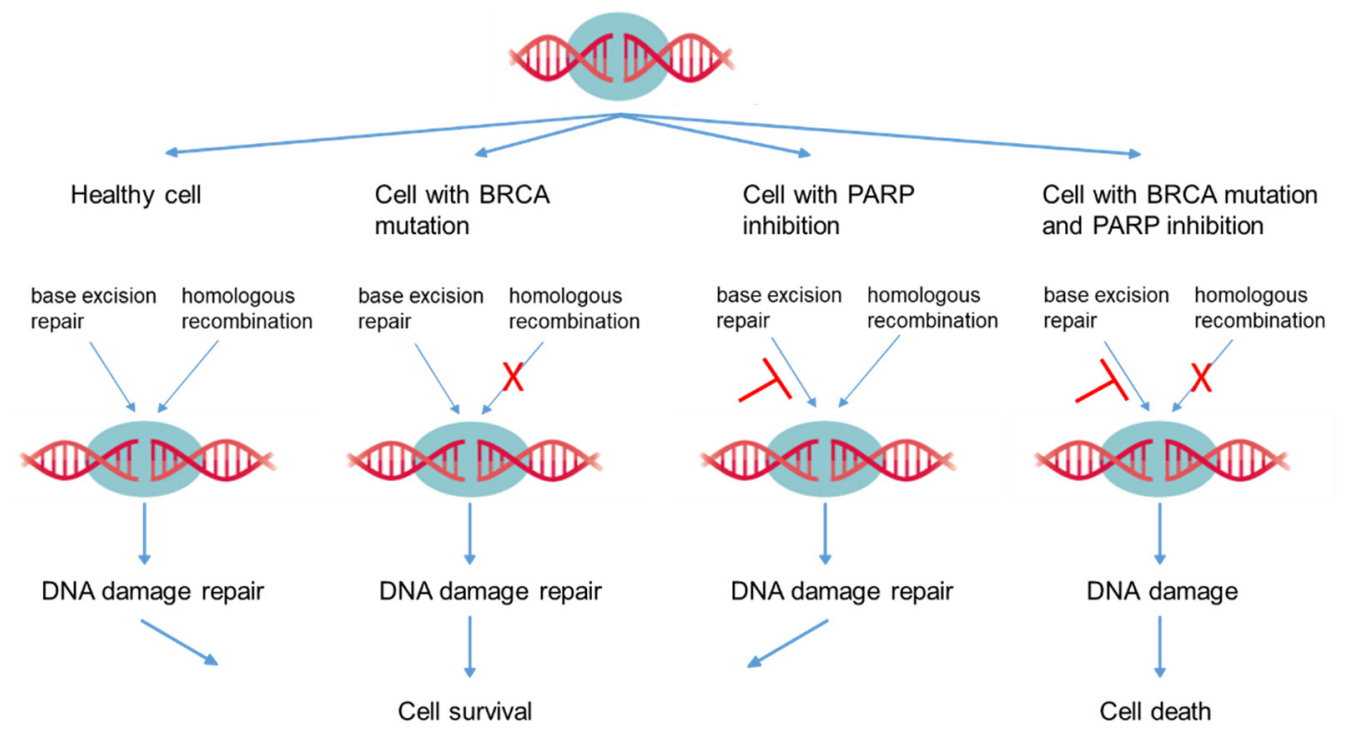

Figure 3. The role of gene defects (e.g., BRCA) and poly (ADP-ribose) polymerase (PARP) inhibition in the process of apoptosis. As an example, the repair of two independent single-strand breaks (or clustered single-strand breaks) is demonstrated $(\mathrm{T}=$ inhibited, $\mathrm{X}=$ blocked). $\mathrm{ROS}$ : reactive oxygen species.

Matrix metalloproteases (MMP-2 and MMP-9), which are required for the invasion into surrounding tissues and tumor metastasis, were shown to be down-regulated by PC $[77,78]$. Furthermore, down-regulation of HIF-1 was shown, which is associated with increased oxygen demand and angiogenesis as well as MCP-1 expression (which is positively correlated with metastatic prognosis in the tumor environment). This down-regulation also promoted MIP-1 expression (which plays a role in reducing angiogenesis) [77].

Similarly, PC induced an increase in calpain-9 activity in colon cancer cells, a cysteine protease, which increases intracellular $\mathrm{Ca}^{2+}$ concentration [78]. It thus contributes to drugmediated apoptosis by down-regulating the peroxisome proliferator-activated receptor $\gamma$ $(\operatorname{PPAR} \gamma)$ expression, which is related to tumor progression. Further anti-tumor mechanisms included inhibition of the colon cancer Wnt $/ \beta$-catenin signaling and down-regulation of peroxisome proliferator-activated receptors $\alpha$ and $\delta$ expression (PPAR $\alpha$, PPAR $\delta$ ) [79].

Cell cycle regulation is of importance in normal cell proliferation, differentiation, and apoptosis, whereby dysfunction of cell cycle regulation is closely related to tumor development [46]. While the normal cell cycle is well regulated, tumor cells might proliferate infinitely. The cell cycle includes three major checkpoints which must be overcome successfully for cell division: the G1/S checkpoint, the G2/M checkpoint, and the spindle checkpoint. Failure to pass one or more of these checkpoints leads to cell cycle arrest and eventually to apoptosis. Supplementation of the cell culture medium with PC led to an arrest in the G0/G1 phase for colorectal tumor cells HT-29 and lung cancer cells A549. The DNA synthesis was thus blocked, and tumor cell proliferation inhibited [63]. Different groups reported that PC could also block $\mathrm{G} 2 / \mathrm{M}$ cell cycle progression. This was found for pancreatic cancer cells PANC-1 [41], for human ovarian cancer cells SKOV-3 [79,80] and hepatoblastoma cells HepG2 [68].

Human breast cancer cells MDA-MB-231 were found to have different degrees of cell cycle arrest in the G0/G1 phase $[29,47]$ by expression of cyclin-dependent kinase (CDK) inhibitor 1 (p21) as well as by down-regulation of Cyclin E and CDK2 expression [65]. Moreover, PC was shown to prevent leukemic cells (K562) from entering the S phase, and the cells were arrested in the G1 phase [35]. Altogether, these mechanisms induced by PC have the effect of inhibiting cell proliferation, and in turn, promoting apoptosis/necrosis [77].

The wide range of proliferation inhibition by PC from $3.7 \%$ to $100 \%$ in different cancer cell lines is striking. One hypothesis that could possibly explain this is the well-known 
genetic heterogeneity of different types of cancers, but there may also be substantial heterogeneity of cancer cells within a tumor. Forty years ago, Nowell reported that intra-tumor evolution via mutation and selection continues after tumor initiation [81]. Deficiencies in DNA repair are known to lead to higher mutation rates than in normal cells [82]. As a result, a tumor may contain a genetically diverse collection of subclones until it is clinically detectable [83]. Therefore, the intra-tumor heterogeneity can lead to the fact that tumor therapy can only lead a part of the tumor cells, but not all cells, into apoptosis/necrosis. This might be one reason why high intra-tumoral heterogeneity was associated with a poorer outcome in conventional tumor therapy in clinical studies [84-86].

\section{Strategies for Potential Phycocyanin-Based Anti-Cancer Therapies}

The effects of PC on tumor cell lines are nowadays quite substantially analyzed in multiple in vitro studies (see Table 1). The data of the sparse in vivo studies are summarized in Table 2. The dataset comprises studies with single and combinatory approaches (drugs and techniques), in oral as well as local treatments (Table 2). PC is currently not clinically used as an anti-cancer drug since the effects of a monotherapy seems to be not efficient enough [51]. In addition, the short in vivo half lifetime of PC puts some limitations to the application in medicine [87].

Very recently, Jiang and coworkers published a study to overcome these hurdles [57] by using a nanoparticle-based delivery system consisting of carboxymethyl chitosan-a material which has been shown to be water soluble, biodegradable, biocompatible and non-toxic [88]. In addition, they added a CD59 specific ligand peptide (CD59sp) to the nanoparticle for tumor targeting. CD59 was reported to be highly expressed in many solid tumors such as colon cancer [89], lung cancer [90], pancreatic cancer [91], and ovarian cancer [82,92], while CD59 was only marginally expressed in normal cells [90]. A first study revealed that the anti-tumor effects of the CD59sp containing the PC delivery system was more effective than the substance alone or the PC delivery system without targeting peptide in vitro (HeLa cells) as well as in vivo (female BALB/c nude mice, [57]). Besides carboxymethyl chitosan nanoparticles, liposome carriers have also been used to incorporate algal ingredients, and were shown to enhance cellular uptake [93].

Another strategy is the functionalization of nanoparticles with PC in combination with other substances, such as hematoporphyrin monomethyl ether for the noninvasive photodynamic anti-cancer therapy (PDT) [94,95]. In liver and breast cancer mouse model studies, PC-coated nanoparticles were injected in the tumor area and excited by nearinfrared (NIR) laser light. This strategy allows the application of PC as a ROS-inducing photosensitizer and further allows for photoacoustic/thermal visualization of the treatment progress due to its fluorescence properties. The locally induced ROS generation results in apoptosis and necrosis. In combination with a further-thermal-treatment, tumor growth was shown to be decreased in these studies without systemic toxic side effects. However, the oral or local application of PC (without nanoparticle-based delivery system) was also shown to reduce tumor weight and forming rate in PDT $[48,96]$.

The combination of PC with other natural compounds from marine organisms, which specifically supplement the effect on tumor cells via different mechanisms, seems to open further avenues for the therapy of tumors. 
Table 2. Overview of in vivo studies investigating the influence of phycocyanin on the growth of various tumors.

\begin{tabular}{|c|c|c|c|c|c|c|}
\hline Tumor Type & Tumor Induction & Animal Model & $\begin{array}{l}\text { Combination } \\
\text { Drug/Technique }\end{array}$ & $\begin{array}{l}\text { Phycocyanin } \\
\text { Concentration }\end{array}$ & $\begin{array}{l}\text { Treatment } \\
\text { Duration }\end{array}$ & Ref. \\
\hline Lung & $\begin{array}{l}\text { Injection of A549 cells } \\
\text { (right flank) }\end{array}$ & Rat (nude) & Betaine & $\begin{array}{c}370.0 \mathrm{mg} / \mathrm{kg} \text { of body } \\
\text { weight per day, } \\
\text { food supplement }\end{array}$ & 28 days & [51] \\
\hline Lung & $\begin{array}{l}\text { Injection of A549 cells } \\
\text { (armpit area) }\end{array}$ & Mouse (nude) & All-trans retinoic acid & $\begin{array}{c}0.2 \mathrm{~mL}(320 \mathrm{mg} / \mathrm{mL}) \text { per } \\
\text { day, injected in tumor area }\end{array}$ & 10 days & {$[52,97]$} \\
\hline Colon & $\begin{array}{l}\text { Injection of 1,2- } \\
\text { dimethyl-hydrazine } \\
\text { dihydro-chloride } \\
\text { (subcutaneous) }\end{array}$ & $\begin{array}{l}\text { Rat, Sprague- } \\
\text { Dawley }\end{array}$ & Piroxicam & $\begin{array}{l}\text { Up to } 200 \mathrm{mg} / \mathrm{kg} \text { body } \\
\text { weight per day, food suppl. }\end{array}$ & 42 days & {$[77,98,99]$} \\
\hline $\begin{array}{l}\text { Ehrlich ascites } \\
\text { carcinoma (EAC) }\end{array}$ & $\begin{array}{l}\text { Injection of EAC cells } \\
\text { (peritoneum) }\end{array}$ & Mouse, Swiss albino & Cisplatin & $\begin{array}{l}0.5 \mathrm{~g} / \mathrm{kg} \text { body weight of } \\
\text { AP, food suppl. }\end{array}$ & $\begin{array}{l}14 \text { days pre } \\
\text { and } 14 \text { days } \\
\text { post inocul. }\end{array}$ & [100] \\
\hline $\begin{array}{l}\text { Esophag. } \\
\text { Squamous cell carc. }\end{array}$ & ESCC EC9706 & Mouse & & Injected in tumor area & & [101] \\
\hline Cervix & $\begin{array}{l}\text { Injection of } \\
\text { SiHa/HeLa cells } \\
\text { (axillary fossa/ } \\
\text { armpit area) }\end{array}$ & Mouse, BALB/c & $\begin{array}{l}\text { Nanoparticles } \\
\text { functionalized: } \\
\text { CD95sp and PC }\end{array}$ & $\begin{array}{l}\text { Injected in tumor area/tail } \\
\text { vein once every } 2 \text { days }\end{array}$ & 20 days & {$[57,102,103]$} \\
\hline Liver & $\begin{array}{l}\text { Injection of H22 cells } \\
\text { (armpit area) }\end{array}$ & Mouse, BALB/c & $\begin{array}{l}\text { Photodynamic } \\
\text { therapy (PDT) }\end{array}$ & $\begin{array}{l}0.02 \mathrm{~mL}(10 \mathrm{mg} / \mathrm{mL}) \text { per } \\
\text { day injected in tumor area }\end{array}$ & 10 days & [96] \\
\hline Breast & $\begin{array}{l}\text { Injection of MCF-7 } \\
\text { cells (spleen area) }\end{array}$ & Mouse, BALB/c & PDT & $2 \mathrm{~mL}(320 \mathrm{mg} / \mathrm{mL})$ per day & 13 days & [48] \\
\hline Breast & $\begin{array}{l}\text { Injection of MCF-7 } \\
\text { cells (right abdomen) }\end{array}$ & Mouse, BALB/c & $\begin{array}{l}\text { PDT, Nanoparticle } \\
\text { coated with } \\
\text { hematoporphyrin } \\
\text { mono-methyl ether } \\
\text { and PC }\end{array}$ & $\begin{array}{c}100 \mu \mathrm{L} \text { nanoparticle } \\
\text { solution }(3 \mu \mathrm{g} / \mathrm{g}) \text { injected } \\
\text { in tumor, per day, once } \\
\text { every } 2 \text { days }\end{array}$ & 14 days & [95] \\
\hline Breast & $\begin{array}{l}\text { Injection of } 4 \mathrm{~T} 1 \text { cells } \\
\text { (subcutaneous) }\end{array}$ & Mouse, BALB/c & $\begin{array}{l}\text { PDT, Nanoparticles } \\
\text { functionalized } \\
\text { with PC }\end{array}$ & $\begin{array}{c}100 \mu \mathrm{L} \text { nanoparticle } \\
\text { solution (cor. } \\
150 \mu \mathrm{g} / \mathrm{mL} \mathrm{PC} \text { ) }\end{array}$ & 14 days & [94] \\
\hline
\end{tabular}

First studies showed that PC can potentially improve the efficacy of currently available anti-cancer drugs [57]. The combination of PC and topotecan to human prostate adenocarcinoma cells (LNCaP) increased the activity of caspase-9 and caspase-3, increased free radical oxygen (ROS) levels, induced apoptosis of tumor cells, and reduced side effects of topotecan in a rat tumor model [104]. The combination of Piroxicam (a traditional nonsteroidal anti-inflammatory drug) with PC in 1,2 dimethylhyadrazine (DMH)-induced rat colon carcinogenesis, showed a more than $70 \%$ higher effect than single-use drugs. DNA fragmentation increased and cyclooxygenase 2 (COX-2) expression and prostaglandin E2 (PGE-2) levels were significantly reduced. In addition, the number and size of tumors were also reduced $[98,99]$. The combination of all-trans retinoic acid (ATRA) with PC could significantly reduce the dose and side effects of ATRA in A549 pulmonary tumor cells. The combination therapy significantly down-regulated anti-apoptotic protein Bcl-2, up-regulated the expression of pro-apoptotic Caspase-3 protein, inhibited cell-cycle-related CDK-4 and Cyclin D1 protein expression, inhibited complement regulatory protein CD59 expression, and induced apoptosis in HeLa cells [52,97]. When lung cancer A549 cells were treated with betaine, A549 cell viability decreased by $50 \%$, and the combination of betaine and PC decreased the viability by an additional 10-20\% [51]. The NF- $\kappa B$ expression was reduced, the amount of pro-apoptotic protein p38 MAPK increased and a G2/M cell cycle arrest was induced [51]. In a very recent animal study in 220 female Swiss albino mice, Hashem et al. found that the combination of AP $(0.5 \mathrm{~g} / \mathrm{kg}$ b.wt., po) in addition to Cisplatin (40 $\mathrm{\mu g} / \mathrm{mouse} / \mathrm{ip})$, an extensively used chemotherapeutic drug with broadspectrum activity, promoted the apoptotic and cytotoxic functions of Cisplatin on the combination group against Ehrlich ascites carcinoma after two weeks of application [100]. Furthermore, AP significantly alleviated the Cisplatin-induced hematotoxic, hepatotoxic, and nephrotoxic impacts in normal mice.

These studies show that the addition of PC to already well-established anti-cancer drugs could improve cancer therapy significantly. In addition, the dosage of the cytostatic might be reduced, what often leads to less severe toxic side effects.

Beyond the mitigation of cancer activity, Ji and colleagues reported the influence of PC on the epithelial-to-mesenchymal transition (EMT) [105]. EMT is a pivotal and intricate process that increases the metastatic potential of cervical cancer. The authors induced EMT 
by TGF- $\beta 1$ in cervical cancer cells. PC inhibited EMT in Caski cells by down-regulating $\mathrm{N}$-cadherin and up-regulating E-cadherin protein expression through the TGF- $\beta$ /smads signaling pathway. Furthermore, C-phycocyanin (C-PC) could inhibit the expression of Twist, Snail and Zeb1 transcription factors related to EMT. In addition, C-PC could inhibit the migration and invasion of Caski cells induced by TGF- $\beta 1$. They concluded that C-PC reversed TGF- $\beta 1$-induced epithelial-to-mesenchymal transition in cervical cancer cells and down-regulated the TGF- $\beta$ /smad signaling pathway [105].

In this respect, it is of considerable importance that PC did not negatively affect non-malignant cells, so that high-dose therapies are possible (see Table 3). In vivo studies showed no toxicity, no adverse effects, and no mortality during acute toxicity tests of PC in rats and mice [106,107]. This applied even to the oral feeding of $3000 \mathrm{mg}$ [106] or $5000 \mathrm{mg}[52,108]$ per $\mathrm{kg}$ body weight. Intraperitoneal administration of $70 \mathrm{mg}$ [109] and even $200 \mathrm{mg}$ PC per kg body weight [110] also revealed no adverse effect in rats.

Table 3. Effects of phycocyanin on growth of non-tumorigenic cell lines and primary cells.

\begin{tabular}{|c|c|c|c|c|c|c|c|c|c|}
\hline \multirow{2}{*}{$\begin{array}{c}\text { Cell Origin } \\
\text { Ovary (Chin. Hamster) }\end{array}$} & \multirow{2}{*}{$\frac{\text { Cell Type }}{\mathrm{CHO}}$} & \multicolumn{2}{|c|}{ Phycocyanin Concentration } & \multirow{2}{*}{$\begin{array}{c}\text { Appl. Time } \\
\text { (h) }\end{array}$} & \multirow{2}{*}{$\begin{array}{c}\text { Prolif. (\%) } \\
\approx\end{array}$} & \multicolumn{2}{|c|}{ IC50 } & \multirow{2}{*}{$\begin{array}{c}\text { Morphology } \\
\text { epithelial }\end{array}$} & \multirow{2}{*}{$\begin{array}{r}\text { Ref. } \\
{[58]}\end{array}$} \\
\hline & & 20 & $\mu \mathrm{M}$ & & & - & - & & \\
\hline Mammary gland & MCF-10A & 25 & $\mu \mathrm{g} / \mathrm{mL}$ & 24 & $\uparrow$ & $>20$ & - & epithelial & [65] \\
\hline Skin & HSF & 1000 & $\mu \mathrm{g} / \mathrm{mL}$ & 24 & $\approx$ & - & - & fibroblast & [62] \\
\hline Skin & CCD-986sk & 40 & $\mu \mathrm{M}$ & 72 & +42 & - & - & fibroblast & [35] \\
\hline Skin & Hs68 & 100 & $\mu \mathrm{M}$ & 72 & $\approx$ & - & - & fibroblast & [49] \\
\hline Liver & LO2 & 100 & $\mu \mathrm{M}$ & 72 & $\approx$ & - & - & & [55] \\
\hline Liver & QSG-7701 & 100 & $\mu \mathrm{M}$ & 72 & $\approx$ & - & - & epithelial & [55] \\
\hline Human heart ventricle & AC-16 & 100 & $\mu \mathrm{M}$ & 72 & $\approx$ & - & - & & [55] \\
\hline Kidney cortex & HK-2 & 100 & $\mu \mathrm{M}$ & 72 & $\approx$ & - & - & epithelial & [55] \\
\hline Peripheral blood & NK-82 & 100 & $\mu \mathrm{M}$ & 72 & $\approx$ & - & - & NK cells & [55] \\
\hline Endothelium of umbilical vein & HUVEC & 100 & $\mu \mathrm{M}$ & 72 & $\approx$ & - & - & epithelial & [55] \\
\hline Endothelium of umbilical vein & HUVEC & 50 & $\mu \mathrm{g} / \mathrm{mL}$ & 80 & +31 & - & - & epithelial & [111] \\
\hline Connective tissue (Mouse) & L929 & 596 & $\mu \mathrm{g} / \mathrm{mL}$ & 24 & -25 & 596 & $\mu \mathrm{g} / \mathrm{mL}$ & fibroblast & [57] \\
\hline
\end{tabular}

-: not given, $\uparrow:$ increase, $\approx$ : approximately equal/unchanged.

\section{Effect of Phycocyanin on Tumor Cells in Comparison to Non-Malignant Cells}

Why PC is toxic to tumor cells but non-toxic to non-malignant cells is still unclear and the subject of much debate. Different molecular pathways can be hypothesized, which might provide access to this enigma, and may help to solve it in the future. Differences in the function of non-malignant cells compared to tumor cells offer an approach to answer this question.

The underlying characteristic of cancer cells is the development of genomic instability, which promotes the development and accumulation of cancer-relevant mutations, finally leading to malignant transformation [46]. One difference between cancer cells and nonmalignant cells consists of genetic or epigenetic changes that can lead to uncontrolled tumor growth. In healthy organisms, genomic stability is controlled by various repair mechanisms. Mammalian cells comprise a variety of repair mechanisms that potentially detect and repair DNA damages, such as single-strand breaks, base adducts, or base oxidations etc., and thus maintain genomic integrity. Important repair systems include base and nucleotide excision repair (BER, NER) as well as double-strand break repair by homologous recombination (HR) or non-homologous end-joining (NHEJ) [8,112]. The poly (ADP-ribose) polymerase (PARP) enzymes PARP-1 and PARP-2 recognize DNA single- and double-strand breaks via their zinc finger binding domains, and contribute to DNA repair by enzymatic activation of the BER or other mechanisms [10-12,113]. By inhibiting PARP, single-strand breaks are no longer repaired and double-strand breaks occur during the next cell division in the nucleus, which then leads to apoptosis.

In non-malignant cells, DNA damages can be repaired by homologous recombination. This context is shown in Figure 3.

PARP inhibitors, when used specifically in patients with BRCA gene defects, offer the possibility of attacking tumor cells and leading them to apoptosis, while in healthy cells in the same organism, the repair of single-strand breaks should continue (see Figure 3). 
Reddy reported that PC has PARP-inhibiting properties possibly mediated by the release of cytochrome $\mathrm{c}$ from mitochondria with the activation of caspase 3 following apoptosis [114]. This cleavage of PARP might then preclude the catalytic domains of PARP and presumably disable PARP from coordinating subsequent repair and maintenance of genome integrity. This has already been achieved in PARP cleavage by PC-mediated apoptosis of K562 cells (lymphoblasts of chronic myelogenous leukemia patients) [42]. This clearly demonstrates that PARP inhibition with PC in combination with a gene defect such as BRCA can lead to the apoptosis of tumor cells.

For many of the tumor types shown in Table 1, mutations of BRCA1 and/or BRCA2 tumor suppressor genes are described [115-119]. Women with such BRCA mutations have a risk of $50-80 \%$ to develop breast cancer by the age of 70 [120], and they have a further risk of $40-65 \%$ to develop ovarian cancer. Men with BRCA mutations have a 2-7 times elevated risk for prostate cancer. Both sexes face a 2-4 times elevated risk for colon or pancreatic cancer [115-119]. AP might be able to induce apoptosis in those tumor types.

Patients with mutations in other key genes within the DNA damage repair pathway may also respond to treatment with PARP inhibitors, and identification of these alterations could significantly increase the percentage of patients that may benefit from PC [121]. Worth mentioning is the RAD51C gene (like BRCA1 located on chromosome 17), which was identified in more detail in 2010 [122]. After BRCA1 and 2, it is the only high-risk gene found so far, and is therefore named BRCA3 [123]. Defects also lead to a significant increase in risk (approximately the same as BRCA1/2): according to current knowledge, about $60 \%$ to $80 \%$ of women with RAD51C mutation develop breast cancer, and $20 \%$ to $40 \%$ develop ovarian cancer. Further gene defects associated with the moderate elevation of a risk to develop breast or ovarian tumor were identified in a population-based family study (COGS study [124]).

\section{Conclusions}

The data indicate that PC may be considered a safe drug to reduce or inhibit tumor cell growth. The combination with other anti-cancer drugs and/or radiation therapy might allow the reduction of the effective dose of established anti-cancer drugs, which would minimize dose-related side effects and improve the therapeutic outcome. Also, encapsulation of PC might prolong the half-lifetime, and could thus improve the effectiveness.

However, one should have in mind, that all the studies shown were performed using cancer cell lines. Prior to clinical use, studies involving primary tumor cells and animals must be performed to prove whether comparable results appear. A study using cells out of a tumor as well as cells from the neighbored healthy tissue is now in preparation and will show whether this hypothesis can solve the enigma of why AP leads to apoptosis of tumor cells but does not harm primary non-malignant human cells.

Author Contributions: F.J., S.K. and J.-H.K. were responsible for the funding acquisition. F.J., J.-H.K. and S.B. designed and conceptualized the review. All authors performed the literature search, original draft preparation, as well as review and editing. F.J and S.B. designed the tables and the figures. All authors revised the manuscript critically. All authors have read and agreed to the published version of the manuscript.

Funding: This research was funded by the European Regional Development Fund (EFRE), grant number 85036717.

Acknowledgments: In this section you can acknowledge any support given which is not covered by the author contribution or funding sections. This may include administrative and technical support, or donations in kind (e.g., materials used for experiments).

Conflicts of Interest: The authors declare no conflict of interest. 


\section{References}

1. Cragg, G.M.; Grothaus, P.G.; Newman, D.J. Impact of Natural Products on Developing New Anti-Cancer Agents. Chem. Rev. 2009, 109, 3012-3043. [CrossRef] [PubMed]

2. Adnan, M.; Oh, K.K.; Azad, O.K.; Shin, M.H.; Wang, M.-H.; Cho, D.H. Kenaf (Hibiscus cannabinus L.) Leaves and Seed as a Potential Source of the Bioactive Compounds: Effects of Various Extraction Solvents on Biological Properties. Life 2020, 10, 223. [CrossRef] [PubMed]

3. Hua, P.; Yu, Z.; Xiong, Y.; Liu, B.; Zhao, L. Regulatory Efficacy of Spirulina platensis Protease Hydrolyzate on Lipid Metabolism and Gut Microbiota in High-Fat Diet-Fed Rats. Int. J. Mol. Sci. 2018, 19, 4023. [CrossRef] [PubMed]

4. Gorczyca, W.; Gong, J.; Ardelt, B.; Traganos, F.; Darzynkiewicz, Z. The cell cycle related differences in susceptibility of HL-60 cells to apoptosis induced by various antitumor agents. Cancer Res. 1993, 53, 3186-3192. [PubMed]

5. Sapp, J. The Prokaryote-Eukaryote Dichotomy: Meanings and Mythology. Microbiol. Mol. Biol. Rev. 2005, 69, 292-305. [CrossRef]

6. El-Sheekh, M.M.; Hamad, S.M.; Gomaa, M. Protective effects of Spirulina on the liver function and hyperlipidemia of rats and human. Braz. Arch. Biol. Technol. 2014, 57, 77-86. [CrossRef]

7. Serban, M.-C.; Sahebkar, A.; Dragan, S.; Stoichescu-Hogea, G.; Ursoniu, S.; Andrica, F.-M.; Banach, M. A systematic review and meta-analysis of the impact of Spirulina supplementation on plasma lipid concentrations. Clin. Nutr. 2016, 35, 842-851. [CrossRef]

8. Chamorro, G.; Salazar, M.; Favila, L.; Bourges, H. Pharmacology and toxicology of Spirulina alga. Rev. Investig. Clin. 1996, 48, 389-399.

9. Simpore, J.; Kabore, F.; Zongo, F.; Dansou, D.; Bere, A.; Pignatelli, S.; Biondi, D.M.; Ruberto, G.; Musumeci, S. Nutrition rehabilitation of undernourished children utilizing Spiruline and Misola. Nutr. J. 2006, 5, 3. [CrossRef]

10. Salazar, M.; Martínez, E.; Madrigal, E.; Ruiz, L.; Chamorro, G. Subchronic toxicity study in mice fed Spirulina maxima. J. Ethnopharmacol. 1998, 62, 235-241. [CrossRef]

11. Marles, R.J.; Barrett, M.L.; Barnes, J.; Chavez, M.L.; Gardiner, P.; Ko, R.; Mahady, G.B.; Dog, T.L.; Sarma, N.D.; Giancaspro, G.I.; et al. United States Pharmacopeia Safety Evaluation of Spirulina. Crit. Rev. Food Sci. Nutr. 2011, 51, 593-604. [CrossRef] [PubMed]

12. Mysliwa-Kurdziel, B. Phycobilins and Phycobiliproteins Used in Food Industry and Medicine. Mini-Rev. Med. Chem. 2017, 17, 1173-1193. [CrossRef] [PubMed]

13. Hu, J.; Li, Y.; Pakpour, S.; Wang, S.; Pan, Z.; Liu, J.; Wei, Q.; She, J.; Cang, H.; Zhang, R. Dose Effects of Orally Administered Spirulina Suspension on Colonic Microbiota in Healthy Mice. Front. Cell. Infect. Microbiol. 2019, 9, 243. [CrossRef]

14. Yu, T.; Wang, Y.; Chen, X.; Xiong, W.; Tang, Y.; Lin, L. Spirulina platensis alleviates chronic inflammation with modulation of gut microbiota and intestinal permeability in rats fed a high-fat diet. J. Cell. Mol. Med. 2020, 24, 8603-8613. [CrossRef] [PubMed]

15. Xie, Y.; Li, W.; Zhu, L.; Zhai, S.; Qin, S.; Du, Z. Effects of phycocyanin in modulating the intestinal microbiota of mice. MicrobiologyOpen 2019, 8, e00825. [CrossRef] [PubMed]

16. Li, W.; Lu, L.; Liu, B.; Qin, S. Effects of phycocyanin on pulmonary and gut microbiota in a radiation-induced pulmonary fibrosis model. Biomed. Pharmacother. 2020, 132, 110826. [CrossRef]

17. Chacón-Lee, T.; González-Mariño, G. Microalgae for "Healthy" Foods-Possibilities and Challenges. Compr. Rev. Food Sci. Food Saf. 2010, 9, 655-675. [CrossRef]

18. Deng, R.; Chow, T.-J. Hypolipidemic, Antioxidant, and Antiinflammatory Activities of Microalgae Spirulina. Cardiovasc. Ther. 2010, 28, e33-e45. [CrossRef]

19. Ferreira-Hermosillo, A.; Torres-Durán, P.V.; Juárez-Oropeza, M.A. Hepatoprotective effects of Spirulina maxima in patients with non-alcoholic fatty liver disease: A case series. J. Med Case Rep. 2010, 4, 103. [CrossRef]

20. Ismail, M.; Hossain, M.; Tanu, A.R.; Shekhar, H.U. Effect of Spirulina Intervention on Oxidative Stress, Antioxidant Status, and Lipid Profile in Chronic Obstructive Pulmonary Disease Patients. BioMed Res. Int. 2015, 2015, 486120. [CrossRef]

21. Kalafati, M.; Jamurtas, A.Z.; Nikolaidis, M.G.; Paschalis, V.; Theodorou, A.A.; Sakellariou, G.K.; Koutedakis, Y.; Kouretas, D. Ergogenic and Antioxidant Effects of Spirulina Supplementation in Humans. Med. Sci. Sports Exerc. 2010, 42, 142-151. [CrossRef] [PubMed]

22. Lee, E.H.; Park, J.-E.; Choi, Y.-J.; Huh, K.-B.; Kim, W.Y. A randomized study to establish the effects of spirulina in type 2 diabetes mellitus patients. Nutr. Res. Pr. 2008, 2, 295-300. [CrossRef] [PubMed]

23. Mazokopakis, E.E.; Starakis, I.K.; Papadomanolaki, M.G.; Mavroeidi, N.G.; Ganotakis, E.S. The hypolipidaemic effects of Spirulina (Arthrospira platensis) supplementation in a Cretan population: A prospective study. J. Sci. Food Agric. 2014, 94, 432-437. [CrossRef] [PubMed]

24. Park, H.J.; Lee, Y.J.; Ryu, H.K.; Kim, M.-H.; Chung, H.W.; Kim, W.Y. A Randomized Double-Blind, Placebo-Controlled Study to Establish the Effects of Spirulina in Elderly Koreans. Ann. Nutr. Metab. 2008, 52, 322-328. [CrossRef]

25. Choi, W.Y.; Lee, H.Y. Effect of Ultrasonic Extraction on Production and Structural Changes of C-Phycocyanin from Marine Spirulina maxima. Int. J. Mol. Sci. 2018, 19, 220. [CrossRef]

26. Challouf, R.; Trabelsi, L.; Ben Dhieb, R.; El Abed, O.; Yahia, A.; Ghozzi, K.; Ben Ammar, J.; Omran, H.; Ben Ouada, H. Evaluation of cytotoxicity and biological activities in extracellular polysaccharides released by cyanobacterium Arthrospira platensis. Braz. Arch. Biol. Technol. 2011, 54, 831-838. [CrossRef]

27. Vaňková, K.; Marková, I.; Jašprová, J.; Dvořák, A.; Subhanová, I.; Zelenka, J.; Novosádová, I.; Rasl, J.; Vomastek, T.; Sobotka, R.; et al. Chlorophyll-Mediated Changes in the Redox Status of Pancreatic Cancer Cells Are Associated with Its Anticancer Effects. Oxidative Med. Cell. Longev. 2018, 2018, 4069167. [CrossRef] 
28. Chen, X.; Chen, Y.; Qu, C.; Pan, Z.; Qin, Y.; Zhang, X.; Liu, W.; Li, D.; Zheng, Q. Vitamin C induces human melanoma A375 cell apoptosis via Bax- and Bcl-2-mediated mitochondrial pathways. Oncol. Lett. 2019, 18, 3880-3886. [CrossRef]

29. Patel, S.N.; Sonani, R.R.; Jakharia, K.; Bhastana, B.; Patel, H.M.; Chaubey, M.G.; Singh, N.K.; Madamwar, D. Antioxidant activity and associated structural attributes of Halomicronema phycoerythrin. Int. J. Biol. Macromol. 2018, 111, 359-369. [CrossRef]

30. Lee, J.-H.; Tachibana, H.; Morinaga, Y.; Fujimura, Y.; Yamada, K. Modulation of proliferation and differentiation of C2C12 skeletal muscle cells by fatty acids. Life Sci. 2009, 84, 415-420. [CrossRef]

31. Jiang, Q.; Elson-Schwab, I.; Courtemanche, C.; Ames, B.N. $\gamma$-Tocopherol and its major metabolite, in contrast to $\alpha$-tocopherol, inhibit cyclooxygenase activity in macrophages and epithelial cells. Proc. Natl. Acad. Sci. USA 2000, 97, 11494-11499. [CrossRef] [PubMed]

32. Hao, S.; Yan, Y.; Li, S.; Zhao, L.; Zhang, C.; Liu, L.; Wang, C. The In Vitro Anti-Tumor Activity of Phycocyanin against Non-Small Cell Lung Cancer Cells. Mar. Drugs 2018, 16, 178. [CrossRef] [PubMed]

33. Adir, N.; Lerner, N. The Crystal Structure of a Novel Unmethylated Form of C-phycocyanin, a Possible Connector between Cores and Rods in Phycobilisomes. J. Biol. Chem. 2003, 278, 25926-25932. [CrossRef] [PubMed]

34. Arteni, A.-A.; Ajlani, G.; Boekema, E.J. Structural organisation of phycobilisomes from Synechocystis sp. strain PCC6803 and their interaction with the membrane. Biochim. Biophys. Acta (BBA) Gen. Subj. 2009, 1787, 272-279. [CrossRef] [PubMed]

35. Liu, Q.; Huang, Y.; Zhang, R.; Cai, T.; Cai, Y. Medical Application ofSpirulina platensisDerived C-Phycocyanin. Evid. Based Complement. Altern. Med. 2016, 2016, 7803846. [CrossRef] [PubMed]

36. Pan, R.; Lu, R.; Zhang, Y.; Zhu, M.; Zhu, W.; Yang, R.; Zhang, E.; Ying, J.; Xu, T.; Yi, H.; et al. Spirulina phycocyanin induces differential protein expression and apoptosis in SKOV-3 cells. Int. J. Biol. Macromol. 2015, 81, 951-959. [CrossRef]

37. Hao, S.; Li, S.; Wang, J.; Zhao, L.; Yan, Y.; Wu, T.; Zhang, J.; Wang, C. C-Phycocyanin Suppresses the In Vitro Proliferation and Migration of Non-Small-Cell Lung Cancer Cells through Reduction of RIPK1/NF-kB Activity. Mar. Drugs 2019, 17, 362. [CrossRef]

38. Hao, S.; Li, S.; Wang, J.; Zhao, L.; Yan, Y.; Cao, Q.; Wu, T.; Liu, L.; Wang, C. Transcriptome Analysis of Phycocyanin-Mediated Inhibitory Functions on Non-Small Cell Lung Cancer A549 Cell Growth. Mar. Drugs 2018, 16, 511. [CrossRef]

39. Catassi, A.; Cesario, A.; Arzani, D.; Menichini, P.; Alama, A.; Bruzzo, C.; Imperatori, A.; Rotolo, N.; Granone, P.; Russo, P. Characterization of apoptosis induced by marine natural products in non small cell lung cancer A549 cells. Cell. Mol. Life Sci. 2006, 63, 2377-2386. [CrossRef]

40. Fernández-Rojas, B.; Hernández-Juárez, J.; Pedraza-Chaverri, J. Nutraceutical properties of phycocyanin. J. Funct. Foods 2014, 11, 375-392. [CrossRef]

41. Wu, X.-J.; Yang, H.; Sheng, Y.; Zhu, Y.; Li, P.-P. Fluorescence Properties of a Novel Cyanobacteriochrome GAF Domain from Spirulina that Exhibits Moderate Dark Reversion. Int. J. Mol. Sci. 2018, 19, 2253. [CrossRef] [PubMed]

42. Subhashini, J.; Mahipal, S.V.; Reddy, M.C.; Reddy, M.M.; Rachamallu, A.; Reddanna, P. Molecular mechanisms in C-Phycocyanin induced apoptosis in human chronic myeloid leukemia cell line-K562. Biochem. Pharmacol. 2004, 68, 453-462. [CrossRef] [PubMed]

43. Eriksen, N.T. Production of phycocyanin-A pigment with applications in biology, biotechnology, foods and medicine. Appl. Microbiol. Biotechnol. 2008, 80, 1-14. [CrossRef] [PubMed]

44. Jung, F.; Krüger-Genge, A.; Waldeck, P.; Küpper, J.-H. Spirulina platensis, a super food? J. Cell. Biotechnol. 2019, 5, 43-54. [CrossRef]

45. Madhyastha, H.; Sivashankari, S.; Vatsala, T. C-phycocyanin from Spirulina fussiformis exposed to blue light demonstrates higher efficacy of in vitro antioxidant activity. Biochem. Eng. J. 2009, 43, 221-224. [CrossRef]

46. Hanahan, D.; Weinberg, R.A. Hallmarks of Cancer: The Next Generation. Cell 2011, 144, 646-674. [CrossRef] [PubMed]

47. Tan, W.; Lu, J.-J.; Huang, M.; Li, Y.; Chen, M.; Wu, G.; Gong, J.; Zhong, Z.; Xu, Z.; Dang, Y.; et al. Anti-cancer natural products isolated from chinese medicinal herbs. Chin. Med. 2011, 6, 27. [CrossRef]

48. Li, B.; Chu, X.; Gao, M.; Li, W. Apoptotic mechanism of MCF-7 breast cells in vivo and in vitro induced by photodynamic therapy with C-phycocyanin. Acta Biochim. Biophys. Sin. 2009, 42, 80-89. [CrossRef]

49. Chen, T.; Wong, Y.-S. In Vitro Antioxidant and Antiproliferative Activities of Selenium-Containing Phycocyanin from SeleniumEnriched Spirulina platensis. J. Agric. Food Chem. 2008, 56, 4352-4358. [CrossRef]

50. Arunasree, K.M.; Roy, K.R.; Reddy, N.P.; Dheeraj, B.; Reddy, G.V.; Reddanna, P. Alteration of mitochondrial membrane potential by Spirulina platensis C-phycocyanin induces apoptosis in the doxorubicinresistant human hepatocellular-carcinoma cell line HepG2. Biotechnol. Appl. Biochem. 2007, 47, 159-167. [CrossRef]

51. Bingula, R.; Dupuis, C.; Pichon, C.; Berthon, J.-Y.; Filaire, M.; Pigeon, L.; Filaire, E. Study of the Effects of Betaine and/or C-Phycocyanin on the Growth of Lung Cancer A549 Cells In Vitroand In Vivo. J. Oncol. 2016, 2016, 8162952. [CrossRef] [PubMed]

52. Li, B.; Gao, M.; Chu, X.-M.; Teng, L.; Lv, C.-Y.; Yang, P.; Yin, Q.-F. The synergistic antitumor effects of all-trans retinoic acid and C-phycocyanin on the lung cancer A549 cells in vitro and in vivo. Eur. J. Pharmacol. 2015, 749, 107-114. [CrossRef] [PubMed]

53. Wang, H.; Liu, Y.; Gao, X.; Carter, C.L.; Liu, Z.-R. The recombinant $\beta$ subunit of C-phycocyanin inhibits cell proliferation and induces apoptosis. Cancer Lett. 2007, 247, 150-158. [CrossRef] [PubMed]

54. Gardeva, E.; Toshkova, R.; Yossifova, L.; Minkova, K.; Ivanova, N.; Gigova, L. Antitumor activity of C-phycocyanin from Arthronema africanum (Cyanophyceae). Braz. Arch. Biol. Technol. 2014, 57, 675-684. [CrossRef]

55. Liao, G.; Gao, B.; Gao, Y.; Yang, X.; Cheng, X.; Ou, Y. Phycocyanin Inhibits Tumorigenic Potential of Pancreatic Cancer Cells: Role of Apoptosis and Autophagy. Sci. Rep. 2016, 6, srep34564. [CrossRef] 
56. Remirez, D.; Ledón, N.; González, R. Role of histamine in the inhibitory effects of phycocyanin in experimental models of allergic inflammatory response. Mediat. Inflamm. 2002, 11, 81-85. [CrossRef]

57. Jiang, L.; Wang, Y.; Zhu, F.; Liu, G.; Liu, H.; Ji, H.; Zheng, S.; Li, B. Molecular Mechanism of Anti-Cancer Activity of the Nano-Drug C-PC/CMC-CD59sp NPs in Cervical Cancer. J. Cancer 2019, 10, 92-104. [CrossRef]

58. Gao, M.-H.; Li, B.; Zhang, X.-C.; Chu, X.-M. Molecular immune mechanism of C-phycocyanin from Spirulina platensis induces apoptosis in HeLa cells in vitro. Biotechnol. Appl. Biochem. 2006, 43, 155-164. [CrossRef]

59. Abu Zaid, A.A.; Hammad, D.M.; Sharaf, E.M. Antioxidant and Anticancer Activity of Spirulina platensis Water Extracts. Int. J. Pharmacol. 2015, 11, 846-851. [CrossRef]

60. Koníčková, R.; Vaňková, K.; Vaníková, J.; Váňová, K.; Muchová, L.; Subhanová, I.; Zadinová, M.; Zelenka, J.; Dvořák, A.; Kolář, M.; et al. Anti-Cancer Effects of Blue-Green Alga Spirulina Platensis, a Natural Source of Bilirubin-like Tetrapyrrolic Compounds. Ann. Hepatol. 2014, 13, 273-283. [CrossRef]

61. Basha, O.M.; A Hafez, R.; El-Ayouty, Y.M.; Mahrous, K.F.; Bareedy, M.H.; Salama, A.M. C-Phycocyanin inhibits cell proliferation and may induce apoptosis in human HepG2 cells. Egypt. J. Immunol. 2008, 15, 161-167. [PubMed]

62. Czerwonka, A.; Kaławaj, K.; Sławińska-Brych, A.; Lemieszek, M.K.; Bartnik, M.; Wojtanowski, K.K.; Zdzisińska, B.; Rzeski, W. Anticancer effect of the water extract of a commercial Spirulina (Arthrospira platensis) product on the human lung cancer A549 cell line. Biomed. Pharmacother. 2018, 106, 292-302. [CrossRef] [PubMed]

63. Thangam, R.; Suresh, V.; Princy, W.A.; Rajkumar, M.; Senthilkumar, N.; Gunasekaran, P.; Rengasamy, R.; Anbazhagan, C.; Krishnasamy, K.; Kannan, S. C-Phycocyanin from Oscillatoria tenuis exhibited an antioxidant and in vitro antiproliferative activity through induction of apoptosis and G0/G1 cell cycle arrest. Food Chem. 2013, 140, 262-272. [CrossRef] [PubMed]

64. Srivastava, A.; Tiwari, R.; Srivastava, V.; Singh, T.B.; Asthana, R.K. Fresh Water Cyanobacteria Geitlerinema sp. CCC728 and Arthrospira sp. CCC729 as an Anticancer Drug Resource. PLoS ONE 2015, 10, e0136838. [CrossRef]

65. Ravi, M.; Tentu, S.; Baskar, G.; Prasad, S.R.; Raghavan, S.; Jayaprakash, P.; Jeyakanthan, J.; Rayala, S.K.; Venkatraman, G. Molecular mechanism of anti-cancer activity of phycocyanin in triple-negative breast cancer cells. BMC Cancer 2015, 15, 1-13. [CrossRef]

66. Safaei, M.; Maleki, H.; Soleimanpour, H.; Norouzy, A.; Zahiri, H.S.; Vali, H.; Noghabi, K.A. Development of a novel method for the purification of C-phycocyanin pigment from a local cyanobacterial strain Limnothrix sp. NS01 and evaluation of its anticancer properties. Sci. Rep. 2019, 9, 1-16. [CrossRef]

67. Pardhasaradhi, B.V.V.; Ali, A.M.; Kumari, A.L.; Reddanna, P.; Khar, A. Phycocyanin-mediated apoptosis in AK-5 tumor cells involves down-regulation of Bcl-2 and generation of ROS. Mol. Cancer Ther. 2003, 2, 1165-1170.

68. Wang, C.-Y.; Wang, X.; Wang, Y.; Zhou, T.; Bai, Y.; Li, Y.-C.; Huang, B. Photosensitization of phycocyanin extracted from Microcystis in human hepatocellular carcinoma cells: Implication of mitochondria-dependent apoptosis. J. Photochem. Photobiol. B Biol. 2012, 117, 70-79. [CrossRef]

69. Beneke, R.; Geisen, C.; Zevnik, B.; Bauch, T.; Müller, W.-U.; Küpper, J.-H.; Möröy, T. DNA Excision Repair and DNA Damage-Induced Apoptosis Are Linked to Poly(ADP-Ribosyl)ation but Have Different Requirements for p53. Mol. Cell. Biol. 2000, 20, 6695-6703. [CrossRef]

70. Oftedal, L.; Selheim, F.; Wahlsten, M.; Sivonen, K.; Døskeland, S.O.; Herfindal, L. Marine Benthic Cyanobacteria Contain ApoptosisInducing Activity Synergizing with Daunorubicin to Kill Leukemia Cells, but not Cardiomyocytes. Mar. Drugs 2010, 8, $2659-2672$. [CrossRef]

71. Davies, G.; Martin, L.-A.; Sacks, N.; Dowsett, M. Cyclooxygenase-2 (COX-2), aromatase and breast cancer:a possible role for COX-2 inhibitors in breast cancer chemoprevention. Ann. Oncol. 2002, 13, 669-678. [CrossRef] [PubMed]

72. Telliez, A.; Furman, C.; Pommery, N.; Hénichart, J.-P. Mechanisms Leading to COX-2 Expression and COX-2 Induced Tumorigenesis: Topical Therapeutic Strategies Targeting COX-2 Expression and Activity. Anti-Cancer Agents Med. Chem. 2006, 6, 187-208. [CrossRef] [PubMed]

73. Yang, S.-C.; Wu, C.-H.; Tu, Y.-K.; Huang, S.-Y.; Chou, P.-C. Exposure to 2,3,7,8-tetrachlorodibenzo-p-dioxin increases the activation of aryl hydrocarbon receptor and is associated with the aggressiveness of osteosarcoma MG-63 osteoblast-like cells. Oncol. Lett. 2018, 16, 3849-3857. [CrossRef] [PubMed]

74. Von Rahden, B.H.; Stein, H.J.; Pühringer, F.; Koch, I.; Langer, R.; Piontek, G.; Siewert, J.R.; Höfler, H.; Sarbia, M. Coexpression of Cyclooxygenases (COX-1, COX-2) and Vascular Endothelial Growth Factors (VEGF-A, VEGF-C) in Esophageal Adenocarcinoma. Cancer Res. 2005, 65, 5038-5044. [CrossRef]

75. Mizuno, R.; Kawada, K.; Sakai, Y. Prostaglandin E2/EP Signaling in the Tumor Microenvironment of Colorectal Cancer. Int. J. Mol. Sci. 2019, 20, 6254. [CrossRef]

76. Noda, M.; Tatsumi, Y.; Tomizawa, M.; Takama, T.; Mitsufuji, S.; Sugihara, H.; Kashima, K.; Hattori, T. Effects of etodolac, a selective cyclooxygenase-2 inhibitor, on the expression of E-cadherin-catenin complexes in gastrointestinal cell lines. J. Gastroenterol. 2002, 37, 896-904. [CrossRef]

77. Saini, M.K.; Sanyal, S.N. Targeting angiogenic pathway for chemoprevention of experimental colon cancer using C-phycocyanin as cyclooxygenase-2 inhibitor. Biochem. Cell Biol. 2014, 92, 206-218. [CrossRef]

78. Krüger-Genge, A.; Blocki, A.; Franke, R.-P.; Jung, F. Vascular Endothelial Cell Biology: An Update. Int. J. Mol. Sci. 2019, $20,4411$. [CrossRef]

79. Jiang, L.; Wang, Y.; Yin, Q.; Liu, G.; Liu, H.; Huang, Y.; Liangqian, J. Phycocyanin: A Potential Drug for Cancer Treatment. J. Cancer 2017, 8, 3416-3429. [CrossRef] 
80. Ying, J.; Ruowang, P.; Ji, H.; Lin, C.; Pan, R.; Zhou, L.; Song, Y.; Zhang, E.; Ren, P.; Chen, J.; et al. Transcriptome analysis of phycocyanin inhibitory effects on SKOV-3 cell proliferation. Gene 2016, 585, 58-64. [CrossRef]

81. Nowell, P.C. The clonal evolution of tumor cell populations. Science 1976, 194, 23-28. [CrossRef] [PubMed]

82. Loeb, L.A.; Springgate, C.F.; Battula, N. Errors in DNA replication as a basis of malignant changes. Cancer Res. 1974, 34, $2311-2321$.

83. Mroz, E.A.; Rocco, J.W.; Rocco, J. The challenges of tumor genetic diversity. Cancer 2016, 123, 917-927. [CrossRef] [PubMed]

84. Mroz, E.A.; Tward, A.M.; Hammon, R.J.; Ren, Y.; Rocco, J. Intra-tumor Genetic Heterogeneity and Mortality in Head and Neck Cancer: Analysis of Data from The Cancer Genome Atlas. PLoS Med. 2015, 12, e1001786. [CrossRef] [PubMed]

85. Mroz, E.A.; Tward, A.D.; Pickering, C.R.; Myers, J.N.; Ferris, R.L.; Rocco, J.W. High intratumor genetic heterogeneity is related to worse outcome in patients with head and neck squamous cell carcinoma. Cancer 2013, 119, 3034-3042. [CrossRef] [PubMed]

86. Pereira, B.; Chin, S.-F.; Rueda, O.M.; Vollan, H.-K.M.; Provenzano, E.; Bardwell, H.A.; Pugh, M.; Jones, L.A.; Russell, R.; Sammut, S.-J.; et al. The somatic mutation profiles of 2433 breast cancers refine their genomic and transcriptomic landscapes. Nat. Commun. 2016, 7, 11479. [CrossRef] [PubMed]

87. Yang, P.; Li, B.; Yin, Q.-F.; Wang, Y.-J. Carboxymethyl chitosan nanoparticles coupled with CD59-specific ligand peptide for targeted delivery of C-phycocyanin to HeLa cells. Tumor Biol. 2017, 39. [CrossRef]

88. Rangasamy, J.; Prabaharan, M.; Nair, S.; Tokura, S.; Tamura, H.; Selvamurugan, N. Novel carboxymethyl derivatives of chitin and chitosan materials and their biomedical applications. Prog. Mater. Sci. 2010, 55, 675-709. [CrossRef]

89. Watson, N.F.S.; Durrant, L.G.; Madjd, Z.; Ellis, I.O.; Scholefield, J.H.; Spendlove, I. Expression of the membrane complement regulatory protein CD59 (protectin) is associated with reduced survival in colorectal cancer patients. Cancer Immunol. Immunother. 2005, 55, 973-980. [CrossRef]

90. Varsano, S.; Rashkovsky, L.; Shapiro, H.; Ophir, D.; Mark-Bentankur, T. Human lung cancer cell lines express cell membrane complement inhibitory proteins and are extremely resistant to complement-mediated lysis; a comparison with normal human respiratory epithelium in vitro, and an insight into mechanism(s) of resistance. Clin. Exp. Immunol. 1998, 113, 173-182. [CrossRef]

91. Crnogorac-Jurcevic, T.; Efthimiou, E.; Nielsen, T.; Loader, J.; Terris, B.; Stamp, G.; Baron, A.; Scarpa, A.; Lemoine, N.R. Expression profiling of microdissected pancreatic adenocarcinomas. Oncogene 2002, 21, 4587-4594. [CrossRef] [PubMed]

92. Mezzanzanica, D.; Balladore, E.; Turatti, F.; Luison, E.; Alberti, P.; Bagnoli, M.; Figini, M.; Mazzoni, A.; Raspagliesi, F.; Oggionni, M.; et al. CD95-Mediated Apoptosis Is Impaired at Receptor Level by Cellular FLICE-Inhibitory Protein (Long Form) in Wild-Type p53 Human Ovarian Carcinoma. Clin. Cancer Res. 2004, 10, 5202-5214. [CrossRef] [PubMed]

93. Hu, L.; Huang, B.; Zuo, M.-M.; Guo, R.-Y.; Wei, H. Preparation of the phycoerythrin subunit liposome in a photodynamic experiment on liver cancer cells. Acta Pharmacol. Sin. 2008, 29, 1539-1546. [CrossRef] [PubMed]

94. Lin, Z.; Jiang, B.; Liang, J.; Wen, C.; Shen, X.-C. Phycocyanin functionalized single-walled carbon nanohorns hybrid for nearinfrared light-mediated cancer phototheranostics. Carbon 2019, 143, 814-827. [CrossRef]

95. Du, S.-W.; Zhang, L.-K.; Han, K.; Chen, S.; Hu, Z.; Guan, Y.; Hu, K.; Yin, L.; Wu, B.; Guan, Y. Combined Phycocyanin and Hematoporphyrin Monomethyl Ether for Breast Cancer Treatment via Photosensitizers Modified Fe3O4 Nanoparticles Inhibiting the Proliferation and Migration of MCF-7 Cells. Biomacromolecules 2017, 19, 31-41. [CrossRef] [PubMed]

96. Liu, Z.; Fu, X.; Huang, W.; Li, C.; Wang, X.; Huang, B. Photodynamic effect and mechanism study of selenium-enriched phycocyanin from Spirulina platensis against liver tumours. J. Photochem. Photobiol. B Biol. 2018, 180, 89-97. [CrossRef]

97. Li, B.; Gao, M.; Lv, C.-Y.; Yang, P.; Yin, Q.-F. Study of the synergistic effects of all-transretinoic acid and C-phycocyanin on the growth and apoptosis of A549 cells. Eur. J. Cancer Prev. 2016, 25, 97-101. [CrossRef]

98. Saini, M.K.; Vaiphei, K.; Sanyal, S.N. Chemoprevention of DMH-induced rat colon carcinoma initiation by combination administration of piroxicam and C-phycocyanin. Mol. Cell. Biochem. 2011, 361, 217-228. [CrossRef]

99. Saini, M.K.; Sanyal, S.N. Piroxicam and c-phycocyanin prevent colon carcinogenesis by inhibition of membrane fluidity and canonical Wnt/ $\beta$-catenin signaling while up-regulating ligand dependent transcription factor PPAR $\gamma$. Biomed. Pharmacother. 2014, 68, 537-550. [CrossRef]

100. Hashem, M.A.; Shoeeb, S.B.; Abd-Elhakim, Y.M.; Mohamed, W.A. The antitumor activity of Arthrospira platensis and/or cisplatin in a murine model of Ehrlich ascites carcinoma with hematinic and hepato-renal protective action. J. Funct. Foods 2020, 66, 103831. [CrossRef]

101. Zhang, X.; Fan, T.; Li, S.; Guan, F.; Zhang, J.; Liu, H. C-Phycocyanin elicited antitumor efficacy via cell-cycle arrest, apoptosis induction, and invasion inhibition in esophageal squamous cell carcinoma. J. Recept. Signal Transduct. 2019, 39, 114-121. [CrossRef] [PubMed]

102. Wang, Y.; Jiang, L.; Yin, Q.; Liu, H.; Liu, G.; Zhu, G.; Li, B. The Targeted Antitumor Effects of C- PC/CMC-CD59sp Nanoparticles on HeLa Cells in Vitro and in Vivo. J. Cancer 2017, 8, 3001-3013. [CrossRef] [PubMed]

103. Liu, G.; Xu, X.; Jiang, L.; Ji, H.; Zhu, F.; Jin, B.; Han, J.; Dong, X.; Yang, F.; Li, B. Targeted Antitumor Mechanism of C-PC/CMCCD55sp Nanospheres in HeLa Cervical Cancer Cells. Front. Pharmacol. 2020, 11, 906. [CrossRef] [PubMed]

104. Gantar, M.; Dhandayuthapani, S.; Rathinavelu, A. Phycocyanin Induces Apoptosis and Enhances the Effect of Topotecan on Prostate Cell Line LNCaP. J. Med. Food 2012, 15, 1091-1095. [CrossRef]

105. Ji, H.; Liu, G.; Han, J.; Zhu, F.; Dong, X.; Li, B. C-phycocyanin inhibits epithelial-to-mesenchymal transition in Caski cells. Cancer Cell Int. 2020, 20,1-11. [CrossRef]

106. Romay, C.; Ledón, N.; González, R. Further studies on anti-inflammatory activity of phycocyanin in some animal models of inflammation. Inflamm. Res. 1998, 47, 334-338. [CrossRef] 
107. Naidu, K.A.; Sarada, R.; Manoj, G.; Khan, M.; Swamy, M.M.; Viswanatha, S.; Murthy, K.N.; Ravishankar, G.; Srinivas, L. Toxicity Assessment Of Phycocyanin-A Blue Colorant From Blue Green Alga Spirulina platensis. Food Biotechnol. 1999, 13, 51-66. [CrossRef]

108. Ou, Y.; Lin, L.; Pan, Q.; Yang, X.; Cheng, X. Preventive effect of phycocyanin from Spirulina platensis on alloxan-injured mice. Environ. Toxicol. Pharmacol. 2012, 34, 721-726. [CrossRef]

109. Gupta, M.; Dwivedi, U.N.; Khandelwal, S. C-Phycocyanin: An effective protective agent against thymic atrophy by tributyltin. Toxicol. Lett. 2011, 204, 2-11. [CrossRef]

110. Vadiraja, B.; Gaikwad, N.; Madyastha, K. Hepatoprotective Effect of C-Phycocyanin: Protection for Carbon Tetrachloride andR-(+)-Pulegone-Mediated Hepatotoxicty in Rats. Biochem. Biophys. Res. Commun. 1998, 249, 428-431. [CrossRef]

111. Krüger-Genge, A.; Steinbrecht, S.; Jung, C.G.H.; Waldeck, P.; Küpper, J.-H.; Storsberg, J.; Jung, F. Effect of an Aqueous Extract of Spirulina Platensis on the Endothelialization Potential of Human Venous Endothelial Cells (HUVEC). Clin. Hemorheol. Microcirc. 2020, accepted.

112. Toss, A.; Cortesi, L. Molecular Mechanisms of PARP Inhibitors in BRCA-related Ovarian Cancer. J. Cancer Sci. Ther. 2013, 5, 409-416. [CrossRef]

113. Morales, J.C.; Li, L.; Fattah, F.J.; Dong, Y.; Bey, E.A.; Patel, M.; Gao, J.; Boothman, D.A. Review of Poly (ADP-ribose) Polymerase (PARP) Mechanisms of Action and Rationale for Targeting in Cancer and Other Diseases. Crit. Rev. Eukaryot. Gene Expr. 2014, 24, 15-28. [CrossRef]

114. Reddy, M.C.; Subhashini, J.; Mahipal, S.; Bhat, V.B.; Reddy, P.S.; Kiranmai, G.; Madyastha, K.; Reddanna, P. C-Phycocyanin, a selective cyclooxygenase-2 inhibitor, induces apoptosis in lipopolysaccharide-stimulated RAW 264.7 macrophages. Biochem. Biophys. Res. Commun. 2003, 304, 385-392. [CrossRef]

115. Chelariu-Raicu, A.; Coleman, R.L. Breast cancer (BRCA) gene testing in ovarian cancer. Chin. Clin. Oncol. 2020, 9, 63. [CrossRef]

116. Wu, C.-E.; Yeh, D.-W.; Pan, Y.-R.; Huang, W.-K.; Chen, M.-H.; Chang, J.W.-C.; Chen, J.-S.; Wang, Y.-C.; Chun-Nan, Y. Chromosomal Instability May Not Be a Predictor for Immune Checkpoint Inhibitors from a Comprehensive Bioinformatics Analysis. Life 2020, 10, 276. [CrossRef]

117. Agata, S.; Tognazzo, S.; Alducci, E.; Matricardi, L.; Moserle, L.; Barana, D.; Montagna, M. Segregation analysis of the BRCA2 c.9227G $>$ T variant in multiple families suggests a pathogenic role in breast and ovarian cancer predisposition. Sci. Rep. 2020, 10, 1-6. [CrossRef]

118. Verdaguer, H.; Acosta, D.; Macarulla, T. A new targeted treatment for patients with a germline BRCA mutation: Olaparib in pancreatic cancer. Futur. Oncol. 2020, 16, 2691-2700. [CrossRef]

119. Abida, W.; Patnaik, A.; Campbell, D.; Shapiro, J.; Bryce, A.H.; McDermott, R.; Sautois, B.; Vogelzang, N.J.; Bambury, R.M.; Voog, E.; et al. Rucaparib in Men With Metastatic Castration-Resistant Prostate Cancer Harboring a BRCA1 or BRCA2 Gene Alteration. J. Clin. Oncol. 2020, 38, 3763-3772. [CrossRef]

120. Deng, C.-X. BRCA1: Cell cycle checkpoint, genetic instability, DNA damage response and cancer evolution. Nucleic Acids Res. 2006, 34, 1416-1426. [CrossRef]

121. Risdon, E.N.; Chau, C.H.; Price, D.K.; Sartor, O.; Figg, W.D. PARP Inhibitors and Prostate Cancer: To Infinity and Beyond BRCA. Oncologist 2021, 26, e115-e129. [CrossRef] [PubMed]

122. Westerink, W.M.; Stevenson, J.C.; Horbach, G.J.; Schoonen, W.G. The development of RAD51C, Cystatin A, p53 and Nrf2 luciferase-reporter assays in metabolically competent HepG2 cells for the assessment of mechanism-based genotoxicity and of oxidative stress in the early research phase of drug development. Mutat. Res. Toxicol. Environ. Mutagen. 2010, 696, 21-40. [CrossRef] [PubMed]

123. Ali, S.; Malik, Z.; Singh, S.S.; Chirom, K.; Ishrat, R.; Malik, Z. Exploring novel key regulators in breast cancer network. PLoS ONE 2018, 13, e0198525. [CrossRef] [PubMed]

124. Chornokur, G.; Lin, H.-Y.; Tyrer, J.P.; Lawrenson, K.; Dennis, J.; Amankwah, E.K.; Qu, X.; Tsai, Y.-Y.; Jim, H.S.L.; Chen, Z.; et al. Common Genetic Variation in Cellular Transport Genes and Epithelial Ovarian Cancer (EOC) Risk. PLoS ONE 2015, 10, e0128106. [CrossRef] 